\title{
Lycopene improves the efficiency of anti-PD-1 therapy via activating IFN signaling of lung cancer cells
}

\author{
Xiufeng Jiang*, Hui Wu, Wei Zhao, Xiao Ding, Qian You, Feng Zhu, Meifang Qian and Ping Yu
}

\begin{abstract}
Background: Monoclonal antibodies targeting programmed death-1 receptor (PD-1) and its ligand (PD-L1) have been developed to treat cancers including lung cancer. In this study, we aimed to investigate whether lycopene could promote the effect of anti-PD-1 treatment on lung cancer.

Methods: Tumor formation assay was conducted. Immune reactions were assessed by detecting several cytokine levels using enzyme-like immunosorbent assay. T cell activity was analyzed using cytometry. The mechanism of lycopene action was investigated using Western blot, quantitative real-time polymerase chain reaction and bisulfite sequencing analysis.

Results: After the mice injected with Lewis lung carcinoma (LLC) cells were sacrificed, we found that combined lycopene and anti-PD-1 reduced the tumor volume and weight compared to control treatment. Cell apoptosis in the tumor tissues was significantly enhanced in mice with combined lycopene and anti-PD-1 treatment in comparison with those of either lycopene or anti-PD-1 alone. Furthermore, lycopene could assist anti-PD-1 to elevate the levels of interleukin (IL)-1 and interferon (IFN) $y$ while reduce the levels of IL-4 and IL-10 in the spleen of mice injected with LLC cells. Lycopene treatment increased the CD4+/CD8+ ratio in the spleen and promoted IFNY-expressing CD8+ T cells in tumor tissues. Upon IFNy stimulation, lycopene diminished PD-L1 expression via activating JAK and repressing phosphorylation of AKT.
\end{abstract}

Conclusion: Our results have demonstrated that lycopene could be used as a potential adjuvant drug to synergistically improve the efficiency of anti-PD-1 therapy.

Keywords: Lung cancer, Lycopene, Programmed death-1 receptor (PD-1), Interferon (IFN) $\gamma$, Interferon-regulatory factor (IRF) proteins

\section{Background}

Lung cancer is one of the most malignant tumors and the leading cause of cancer death worldwide [1,2]. Only $18 \%$ of patients survive from lung cancer [2]. However, most patients are diagnosed in advanced stages with less than $5 \%$ patients survive for 5 years [3]. The first-line treatment depends on genetic aberration of patients. For example, drugs targeting epidermal growth factor receptor (EGFR) and translocation of anaplastic

*Correspondence: jiangxiufeng12@163.com

Department of Respiratory Medicine, The Fifth People's Hospital of Wuxi City, Wuxi 214016, China lymphoma kinase (ALK) have been applied in patients with EGFR mutation or ALK translocation [4, 5]. However, for patients without those oncogenic drivers, cytotoxic chemotherapy is commonly applied. Nevertheless, poor prognosis and drug resistance are still obstructions for the efficiency of current treatments. Therefore, recent attempts have begun to focus on treating lung cancer by modulating the immune reactions.

Recently developed drugs that regulate specific immune checkpoints, and monoclonal antibodies targeting programmed death-1 receptor (PD-1) and its ligand (PD-L1), have all showed impressive anti-tumor effects [6-9]. PD-1 is a cell surface protein containing 288

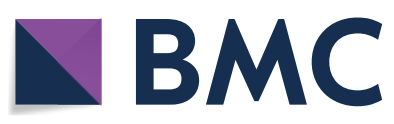

(c) The Author(s) 2019. This article is distributed under the terms of the Creative Commons Attribution 4.0 International License (http://creativecommons.org/licenses/by/4.0/), which permits unrestricted use, distribution, and reproduction in any medium, provided you give appropriate credit to the original author(s) and the source, provide a link to the Creative Commons license, and indicate if changes were made. The Creative Commons Public Domain Dedication waiver (http://creativecommons.org/ publicdomain/zero/1.0/) applies to the data made available in this article, unless otherwise stated. 
amino acid. It has two ligands, PD-L1 and PD-L2. Studies have evidenced that high expression of PD-L1 has been observed in numerous cancers and is associated with poor outcomes [10]. PD-L1 expression in tumor cells facilitates their escape from immune system surveillance. Among all patients with advanced non-small cell lung cancer (NSCLC), more than 20\% showed PD-L1 expression in at least half of tumor cells $[8,11]$. Therefore, improving the efficiency of anti-PD-1 therapy could yield promising outcomes.

Previous results have indicated that lycopene exerts anti-tumor effects by altering the methylation of genes through inhibiting DNA methyltransferase (DNMT) enzyme activity $[12,13]$. DNMT inhibitors have been shown to enhance the efficacy of anti-PD-1 therapy in the treatment of lung cancer by activating interferon (IFN) signaling [14]. Here, we sought to investigate whether lycopene could promote the effects of anti-PD-1 treatment on lung cancer. A series of results confirmed that lycopene promoted anti-PD-1 therapeutic efficiency of lung cancer by promoting IFN $\gamma$-expressing CD8+ cells infiltrated in tumor tissues and increasing IFN $\gamma$ expression in tumor cells.

\section{Methods}

\section{Tumor formation assay}

The effect of combined therapy was detected in vivo. Lewis lung carcinoma (LLC) cells $\left(1 \times 10^{6}\right)$ were injected in the rear flak of C57BL/6 mice. Anti-mouse PD-1 antibodies $(6 \mathrm{mg} / \mathrm{kg})$ were administrated by intraperitoneal injection 3 days apart for 4 times. Lycopene $(40 \mathrm{mg} / \mathrm{kg})$ was intraperitoneally injected daily. Tumor volume and weight were measured. Tumor volume $\left(\mathrm{mm}^{3}\right)$ was calculated using (length $\times$ width $\left.^{2}\right) / 2$. The animal study was approved by the Ethical Committee of the Fifth People's Hospital of Wuxi City. Mice were sacrificed to obtain tumor tissues.

\section{Enzyme-like immunosorbent assay (ELISA)}

The cytokine levels in the spleen were measured using ELISA. Briefly, the spleen of mice was obtained and minced in phosphate buffered saline. The levels of interleukin (IL)-2, interferon (IFN) $\gamma$, IL-4 and IL-10 were detected in triplicates by ELISA kits (Groundwork Biotechnology Diagnosticate, USA) according to the manufacturers' instructions. The color absorbance was measured at $450 \mathrm{~nm}$ with an ELISA plate reader (SoftMax Pro 5.3).

\section{Flow cytometry assay}

The spleen or tumor tissues were mechanically disrupted using a gentleMACS ${ }^{\text {TM }}$ dissociator (Miltenyi Biotec, Bergisch Gladbach, Germany) in 4-(2-hydroxyethyl)-1-piperazineethanesulfonic acid buffer to isolate cells for flow cytometry. Cells were then stained with fluorescently-labeled antibodies including anti-CD8 PE (Biolegend, San Diego, CA, USA), antiCD4 (L3T4) FITC (Biolegend, San Diego, CA, USA) and anti-IFN- $\gamma$ (BD Biosciences, Franklin Lakes, NJ, USA). For apoptosis analysis, perforin and granzyme $\mathrm{B}$ were employed.

\section{Quantitative real-time polymerase chain reaction (qRT-PCR)}

Total RNA was extracted from tumor tissues or LLC cells using Trizol reagent (TaKaRa, Dalian, China). For cDNA synthesis, $2 \mu \mathrm{g}$ RNA was used and ThermoScript RT-PCR System (Invitrogen, Waltham, MA USA) was applied according to manufactures' instructions. The expression levels of IFN $\beta$, IFN $\gamma$, CXCL9, CXCL10, PD-L1, IRF1/7 and IRF3/8 were detected and normalized to GAPDH. The primers were listed in Table 1.

\section{Bisulfite sequencing analysis}

The DNA methylation of IRF1/7 promoter was analyzed by bisulfite sequencing. Briefly, the genomic DNAs obtained from tumor tissues or cells were subjected to bisulfite treatment. The methylation status of IRF1/7 was determined by methylation specific PCR using AmpliTaq Gold (Perkin-Elmer, MA, USA). Methylation specific primers are listed in Table 2.

\section{Western blot}

Total proteins were extracted by cell lysis buffer $(20 \mathrm{mM}$ $\mathrm{NaCl}, 10 \%$ glycerol, $1 \%$ Triton X-100). To separate proteins, $10 \%$ sodium dodecyl sulfate polyacrylamide gel electrophoresis was employed. Proteins were then transferred to Immobilon-P membranes (Millipore, Bedford, MA, USA) and incubated with primary antibodies overnight at $4{ }^{\circ} \mathrm{C}$. Anti-DNMT1, anti-DNMT-3a,

Table 1 Primer sequences used for real-time PCR

\begin{tabular}{lll}
\hline Gene & Forward primer $\left(\mathbf{5}^{\prime} \mathbf{-} \mathbf{3}^{\prime} \mathbf{)}\right.$ & Reverse primer $\left(\mathbf{5}^{\prime} \mathbf{-} \mathbf{3}^{\prime} \mathbf{)}\right.$ \\
\hline IFN & AGCTCCAAGAAAGGACGAACA & GCCCTGTAGGTGAGGTTGAT \\
IFNy & ACACTGCATCTTGGCTTTGC & GCTTTCAATGACTGTGCCGT \\
IRF1 & GGCCGATACAAAGCAGGAGAA & GGAGTTCATGGCACAACGGA \\
IRF7 & TCCAGTTGATCCGCATAAGGT & CTTCCCTATTTTCCGTGGCTG \\
IRF3 & TACACTGAGGACTTGCTG & AAGATGGTGGTCTCCTGATCC \\
& GAGGT & \\
IRF8 & CGAGGTTACGCTGTGCTTTG & TTATGCTTGGCTCTGTGGGG \\
PDL-1 & GCTCCAAAGGACTTGTACGTG & TGATCTGAAGGGCAGCATTTC \\
CXCL9 & GGAGTTCGAGGAACCCTAGTG & GGGATTTGTAGTGGATCGTGC \\
CXCL10 & CCAAGTGCTGCCGTCATTTTC & GGCTCGCAGGGATGATTTCAA \\
Gapdh & AGGTCGGTGTGAACGGATTTG & GGGGTCGTTGATGGCAACA \\
\hline
\end{tabular}


Table 2 Primers for methylation-specific PCR

\begin{tabular}{lll}
\hline Gene & Forward primer $\left(\mathbf{5}^{\prime} \mathbf{-} \mathbf{3}^{\prime}\right)$ & Reverse primer $\left(\mathbf{5}^{\prime} \mathbf{-} \mathbf{3}^{\prime} \mathbf{)}\right.$ \\
\hline IRF1 methylated & TGAAAGATGGTTTT & GACTACGTACCGTCATTT \\
& AGGAGTAGTC & CGAA \\
IRF1 unmethylated & AAAGATGGTTTTAGG & ACCAACTACATACCATCA \\
& AGTTAGTTGG & TTTCAAA \\
IRF7 methylated & TAGATTATTTGAGGTCGG & AAAAAAACAACTACACCG \\
& GAGTTC & TTTACGT \\
IRF7 unmethylated & TAGATTATTTGAGGTGG & AAAAAACAACTACACCAT \\
& GAGTTTG & TTACATT
\end{tabular}

anti-DNMT3b, anti-PD-L1, anti-pJAK2, anti-JAK2, antip-STAT3, anti-STAT3, anti-p-AKT, anti-AKT and anti- $\beta$ actin were purchased from Sigma (St. Louis, MO, USA). All primary antibodies were diluted at 1:1000. After incubating with secondary antibody, the membranes were developed with Enhanced Chemiluminescence Plus Western Detection kit (Amersham Pharmacia Biotech, Piscataway, NJ, USA). For all quantization results of Western blotting, densitometry analysis was used. The values were obtained by dividing the optical density values of interested proteins by it of $\beta$-actin. The results were counted and plotted.

\section{Statistical analysis}

All data were presented as mean \pm standard deviation (SD). Statistical analysis was performed using SPSS 19.0 (IBM., Chicago, IL, US) and Graphpad Prism 7 (Graphpad Inc., La Jolla, CA, US). Statistical significance was assessed using analysis of variance (ANOVA), unpaired t-tests or Mann-Whitney U-tests. $p$ value of less than 0.05 was regarded as statistically significant.

\section{Results}

Lycopene improves the efficiency of anti-PD-1 therapy in NSCLC

To investigate whether lycopene could enhance the efficiency of anti-PD-1 therapy, we performed tumor formation assay in the rear flank of C57BL/6 mice using LLC cells. Anti-PD-1 and lycopene treatments both inhibited tumorigenesis of LLC. Anti-PD-1 antibodies and lycopene were administrated by intraperitoneal injection. Surprisingly, when anti-PD-1 was combined with lycopene, tumor formation was further repressed (Fig. 1a, Additional file 1: Figure S1). The volume and weight of all tumors were also measured (Fig. 1b, c). Lycopene or antiPD-1 treatment alone could reduce tumor volume and weight compared to untreated mice. When anti-PD-1

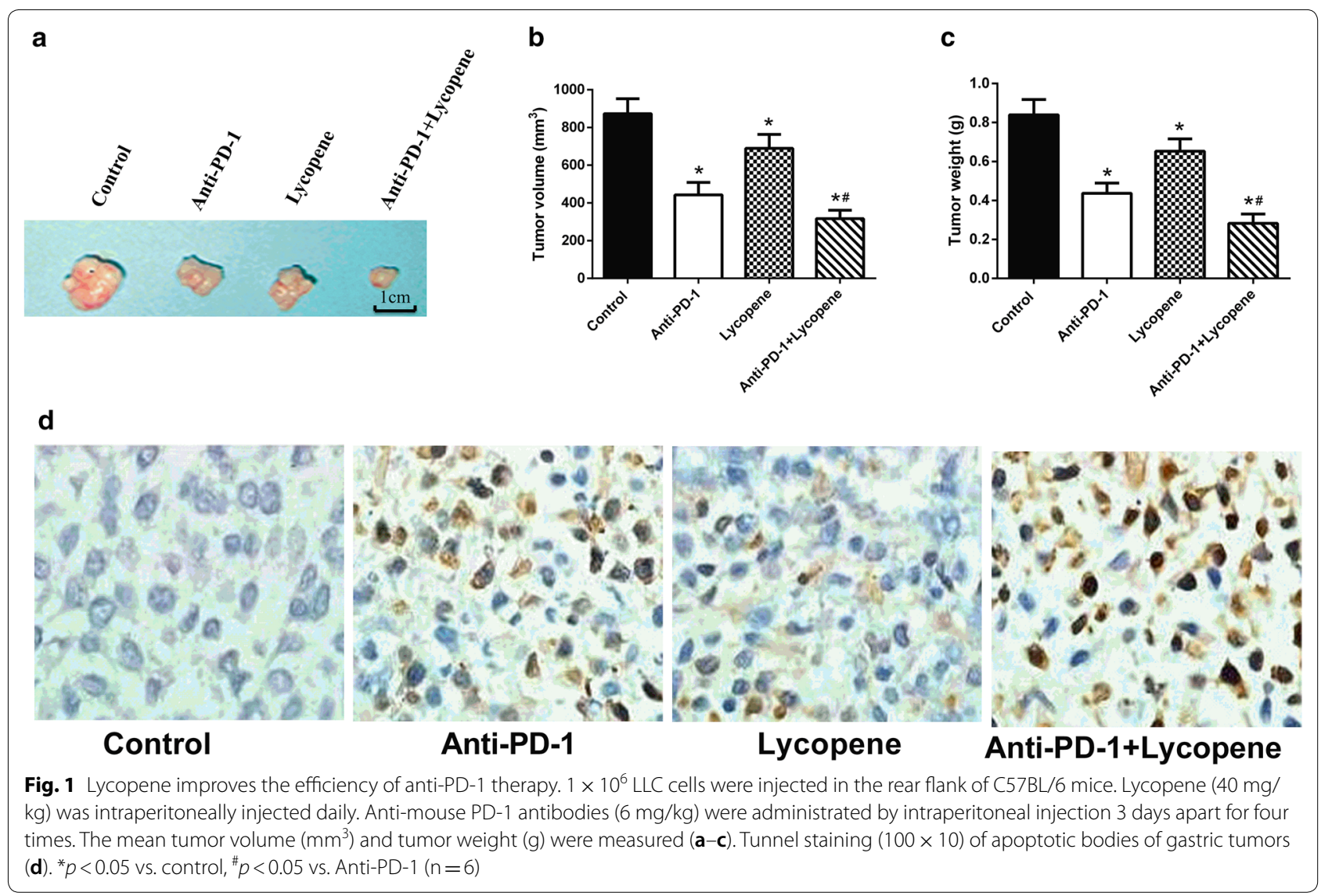


combined with lycopene was applied to mice, it showed more pronounced inhibitory effect on tumor growth. Additionally, cell apoptosis was measured in these tumor tissues. Although lycopene alone showed little effect on cell apoptosis, we found that lycopene combined with anti-PD-1 treatment significantly enhanced cell apoptosis compared to either lycopene or anti-PD-1 treatment alone (Fig. 1d).

The combined lycopene and anti-PD-1 therapy alters the immune responses of mice and promoted death of tumor cells

Since anti-PD-1 therapy prevents the escape of tumor cells from $\mathrm{T}$ cells, we then investigated the mechanism underlying how lycopene synergistically functioned with anti-PD-1. We tested the levels of IL-2, IFN $\gamma$, IL-4 and IL10 in the spleen and found that lycopene showed similar functions as anti-PD-1 in promoting the productions of IL-2 and IFNy (Fig. 2a, b). These effects of lycopene and anti-PD-1 could be reinforced when combined together. In addition, it was observed that either antiPD-1 or lycopene led to increased CD4+/CD8+ ratio in the spleen (Fig. 2c, d). Furthermore, we found that lycopene could synergistically function with anti-PD-1 to improve IFN $\gamma$ expression of CD8+ cells infiltrated in the tumor tissues (Fig. 3a). In addition, we tested cell death in those tumor tissues by analyzing Granzyme B+/CD8+ and perforin $+/ C D 8+$ population using flow cytometry. It was found that combined use of lycopene and antiPD-1 led to significant increase of cell death compared to either lycopene or anti-PD-1 treatment alone (Fig. 3b, c).
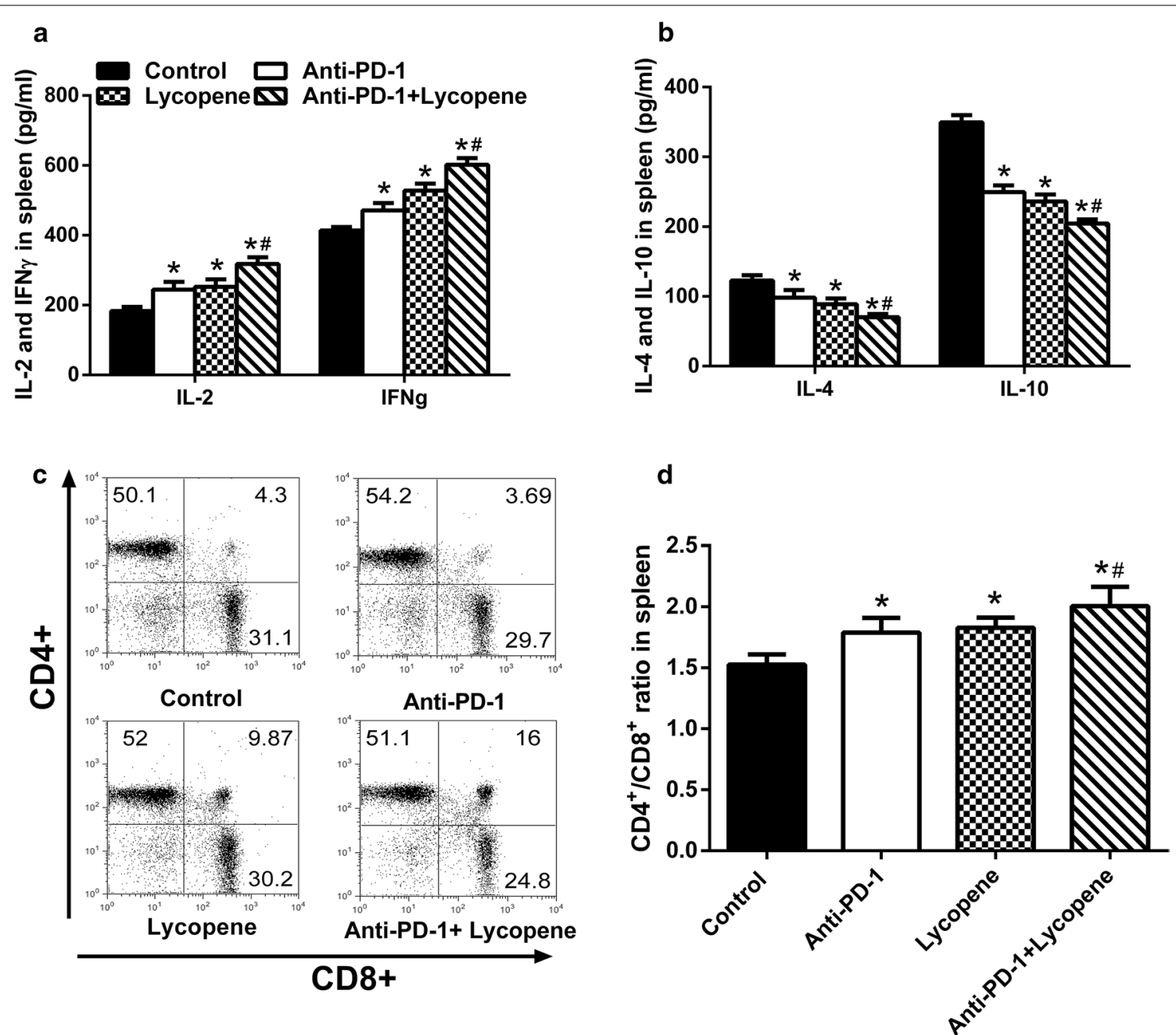

Fig. 2 The combined therapy of lycopene and anti-PD-1 synergistically regulates the immune system. The inflammatory factors in the spleen were detected by ELISA $(\mathbf{a}, \mathbf{b})$. The CD4+/CD8+ ratio in the spleen was measured by flow cytometry analysis $(\mathbf{c}, \mathbf{d})$. IFNy+/CD8+T-cells infiltrated in the tumor tissues were determined by flow cytometry analysis (d). ${ }^{*} p<0.05$ vs. control, ${ }^{*} p<0.05$ vs. Anti-PD-1 $(n=6)$ 

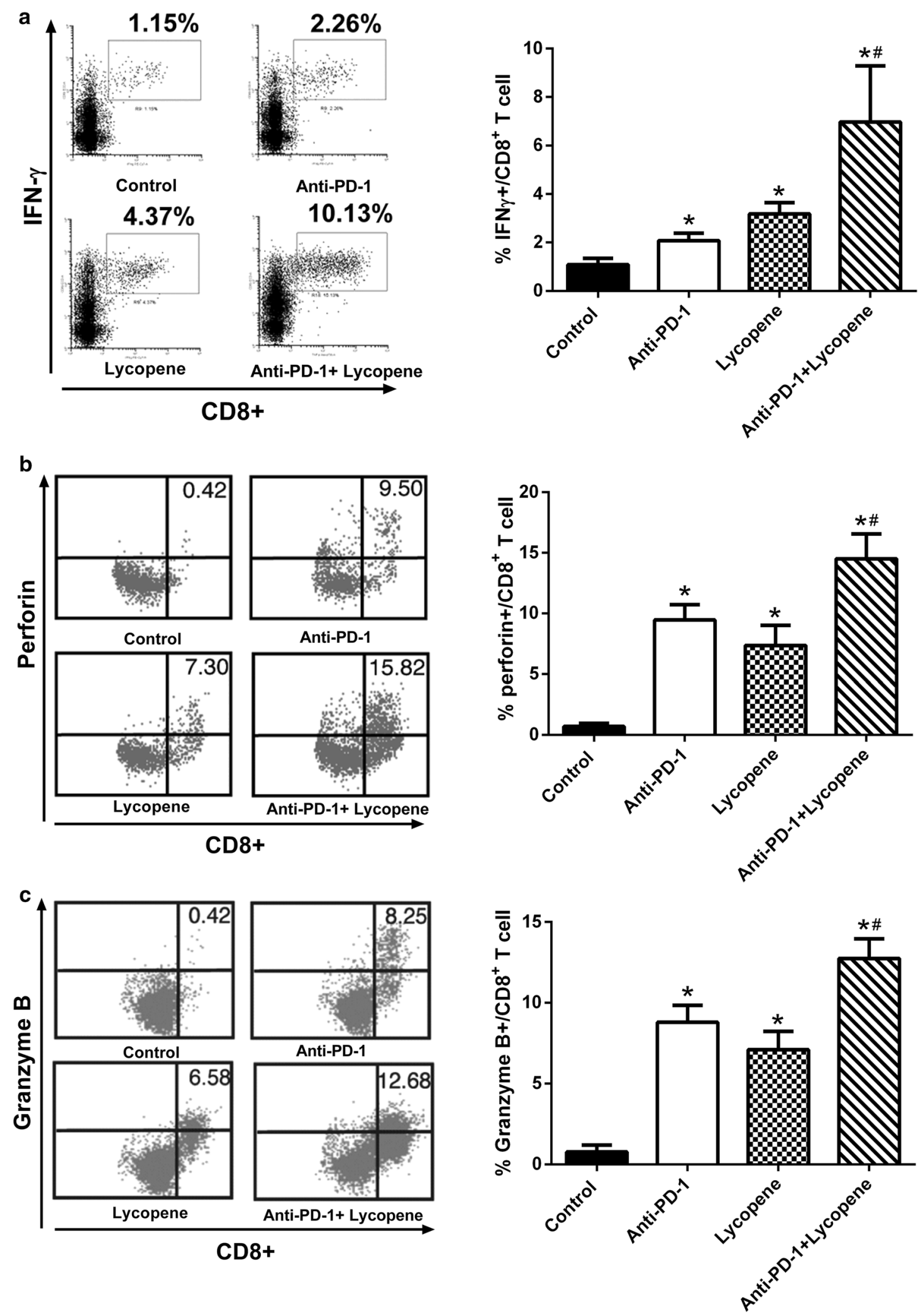

Fig. 3 The combined therapy of lycopene and anti-PD-1 synergistically regulates cancer cell death cytokine. IFNy+/CD8+ (a), perforin+/CD8+ (b) granzyme $\mathrm{B}+/ \mathrm{CD} 8+(\mathbf{d})$ population in tumor-infiltrated T cells was measured by flow cytometry analysis. ${ }^{*} p<0.05$ vs. control, ${ }^{\#} p<0.05$ vs. Anti-PD-1 $(n=6)$ 
a

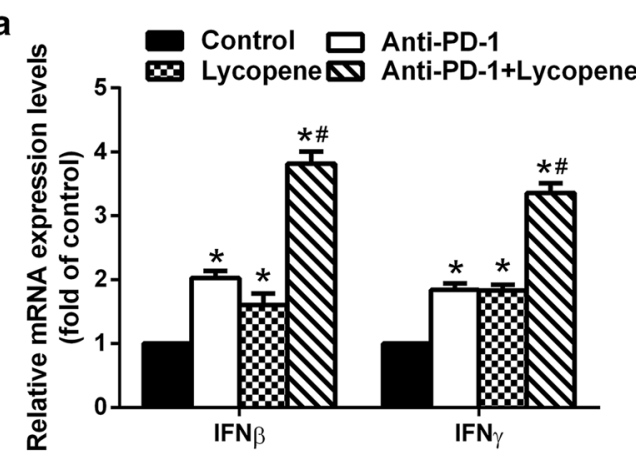

C

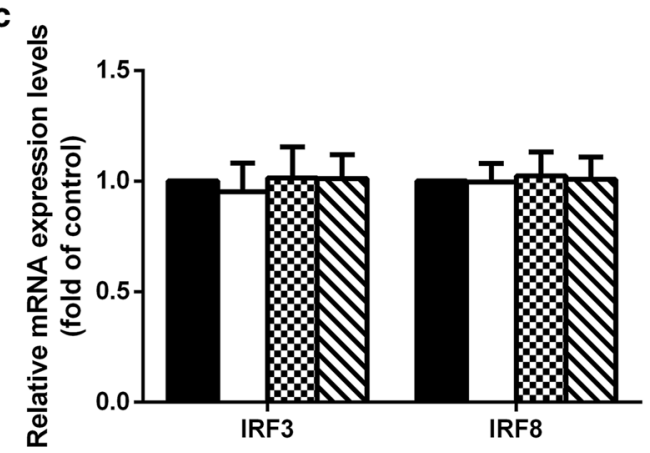

b

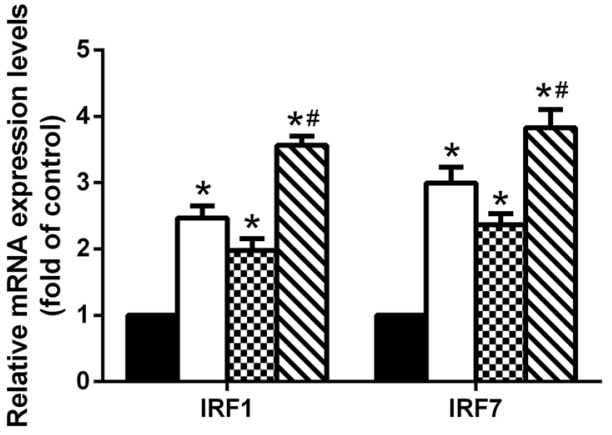

d

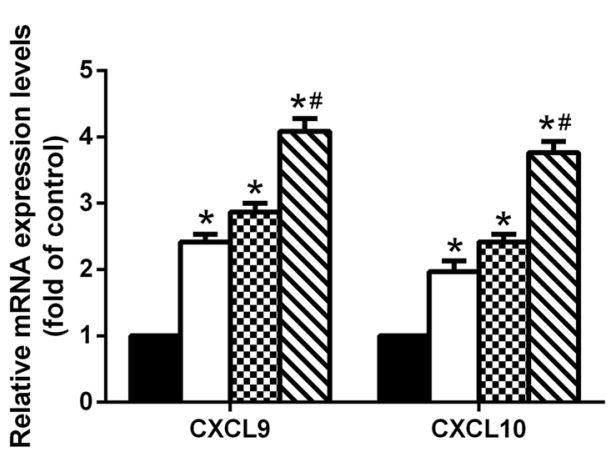

IRF7 e

IRF 1
Control

Anti-PD-1  888888888888888

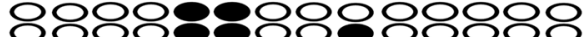

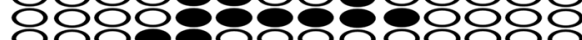

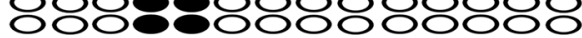

Lycopene

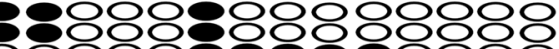
-

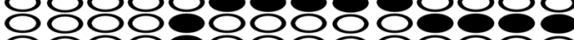

Anti-PD- 1 +Lycopene f

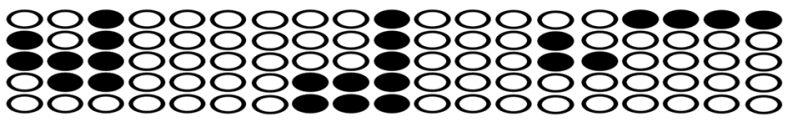

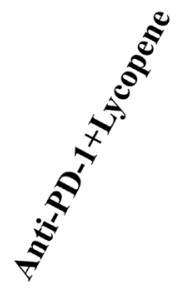

DNMT1

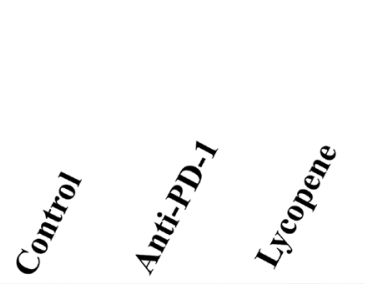

g

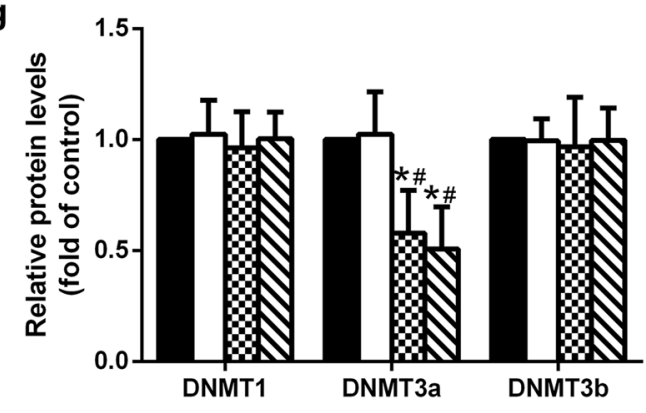

$\beta$-actin 
(See figure on previous page.)

Fig. 4 Lycopene reduces the methylation levels of IRF1 and IRF7 promoters to promote IFNy expression. The IFN-related gene expressions were measured by qRT-PCR (a-d). After the treatment of lycopene and/or PD-1 therapy, the methylation status of IRF1/7 promoter regions were assessed by bisulfite sequencing analysis, (black circle, methylated cytosine of $\mathrm{CpG}$; white circle, unmethylated cytosine of $\mathrm{CpG}$ ) (e). The expression levels of DNMT1, DNMT3A, and DNMT3B in the tumor tissues were analyzed by Western blot (f, $\mathbf{g}){ }^{*} p<0.05$ vs. control, ${ }^{*} p<0.05$ vs. Anti-PD-1 ( $\left.n=6\right)$

\section{Lycopene reduces the methylation levels of IRF1 and IRF7 promoters to promote IFN $\gamma$ expression}

We further investigated whether lycopene regulated the mRNA level of IFN $\gamma$. We found that, in the tumor tissue obtained from mice, lycopene significantly upregulated the mRNA levels of IFN $\beta$, IFN $\gamma$, IRF1, IRF7, CXCL9 and CXCL10, whereas no effect was observed on IRF3 and IRF8 (Fig. 4a-d). To explore the mechanism underlying lycopene regulation on the expression of these factors, we further tested the promoter methylation levels of IRF1 and IRF7. It was observed that the methylation levels on the promoters of IRF1 and IRF7 showed decreased trend in the mice administrated with lycopene and antiPD-1, compared to those in the untreated mice as well as mice with either lycopene or anti-PD-1 alone (Fig. 4e). We next measured the levels of DNMT1, DNMT3A and DNMT3B in these tumor tissues. It was found that the DNMT3a level was dramatically repressed when mice were treated with combined lycopene and anti-PD-1, compared to that of mice with lycopene or anti-PD-1 alone treatment (Fig. 4f, g). Interestingly, the methylation status of IRF3/8 promoter regions was not changed by the treatment of lycopene and/or PD-1 therapy (Additional file 1: Figure S2).

\section{The effect of lycopene on the expression of IFNY-related genes in LLC cells}

We then tested the expression of IFN $\gamma$-related genes in LLC cells treated with or without lycopene. We found that lycopene remarkably increased the mRNA and protein levels of IRF1 and IRF7 in a dose-dependent manner (Fig. 5a, b). The mRNA levels of IFN $\beta$, IFN $\gamma$, CXCL9 and CXCL10 were also upregulated by lycopene (Fig. 5c, d). Consistently, lycopene treatment repressed promoter methylation of IRF1 and IRF7 in a dose-dependent manner (Fig. 5e). The inhibitory effect of lycopene on DNMT3a was also observed in LLC cells (Fig. 5f, g).

\section{The effect and mechanism of lycopene on the expression of PDL-1 downstream of IFN $\gamma$ signaling}

IFN $\gamma$ exerts anti-tumor function mainly through JAK2 signaling. It is also able to promote PDL-1 expression via AKT signaling. Therefore, we further tested the effect of lycopene on PDL-1 expression. No change was observed in the mice with or without lycopene treatment (Fig. 6a, b). Interestingly, when we stimulated LLC cells with IFNy for $30 \mathrm{~min}$, lycopene treatment showed inhibitory effects on PD-L1 expression (Fig. 6c, d). Additionally, we found that lycopene promoted JAK2 signaling but blocked AKT signaling (Fig. 6e, f). These conclusions were confirmed when using a PI3 K-AKT inhibitor, LY294002, which significantly repressed PD-L1 protein level in IFN $\gamma$ and lycopene treated cells (Additional file 1: Figure S3).

\section{Discussion}

About 20\% of patients with advanced NSCLC showed responses to an antibody targeting $\mathrm{PD}-1$, pembrolizumab $[6,15]$. Investigations have demonstrated several factors that impact the sensitivity to pembrolizumab, including EGFR mutations, ALK rearrangements and mutational landscape [16]. Additionally, few patients show strong reactions to anti-PD-1. Therefore, it is urgent to improve the efficiency of anti-PD-1 therapy.

In the present study, we demonstrated that both anti-PD-1 and lycopene alone had the ability to repress tumorigenesis. When combining anti-PD-1 therapy with lycopene, their anti-tumor effect was significantly increased. Although there were a series of studies demonstrating that lycopene intake was associated with decreased risks of prostate, gastric, breast, and lung cancers [17-21], whether it could synergistically function with anti-PD-1 therapy has not been reported. Here, we found that lycopene synergistically exerts anti-tumor function with anti-PD-1. In addition, cell apoptosis and cell death were promoted in the tumors of mice treated with combined lycopene and anti-PD-1. These results suggest that lycopene promotes anti-PD-1 effects on cytotoxic CD8 cells, which on the other hand increases cell death.

Since lycopene has been reported to play a role in the immune system, it is possible that the increased efficiency of anti-PD-1 therapy by lycopene is mediated through its functions in regulating immune response. Previous evidence indicated that lycopene inhibited inflammatory responses through blocking IкB kinase, reducing Toll-like receptor 4 expressions and the productions of several NF-kB-related cytokines such as Tumor necrosis factor- $\alpha$, IL- $1 \beta$ and IL- $6 \beta[21,22]$. It is known that blocking PD-1 unleashes the T cells to target tumor cells. Therefore, based on the surprising effects of lycopene on anti-PD-1 treated lung cancer, we further investigated whether lycopene affected $\mathrm{T}$ cell activities. As 


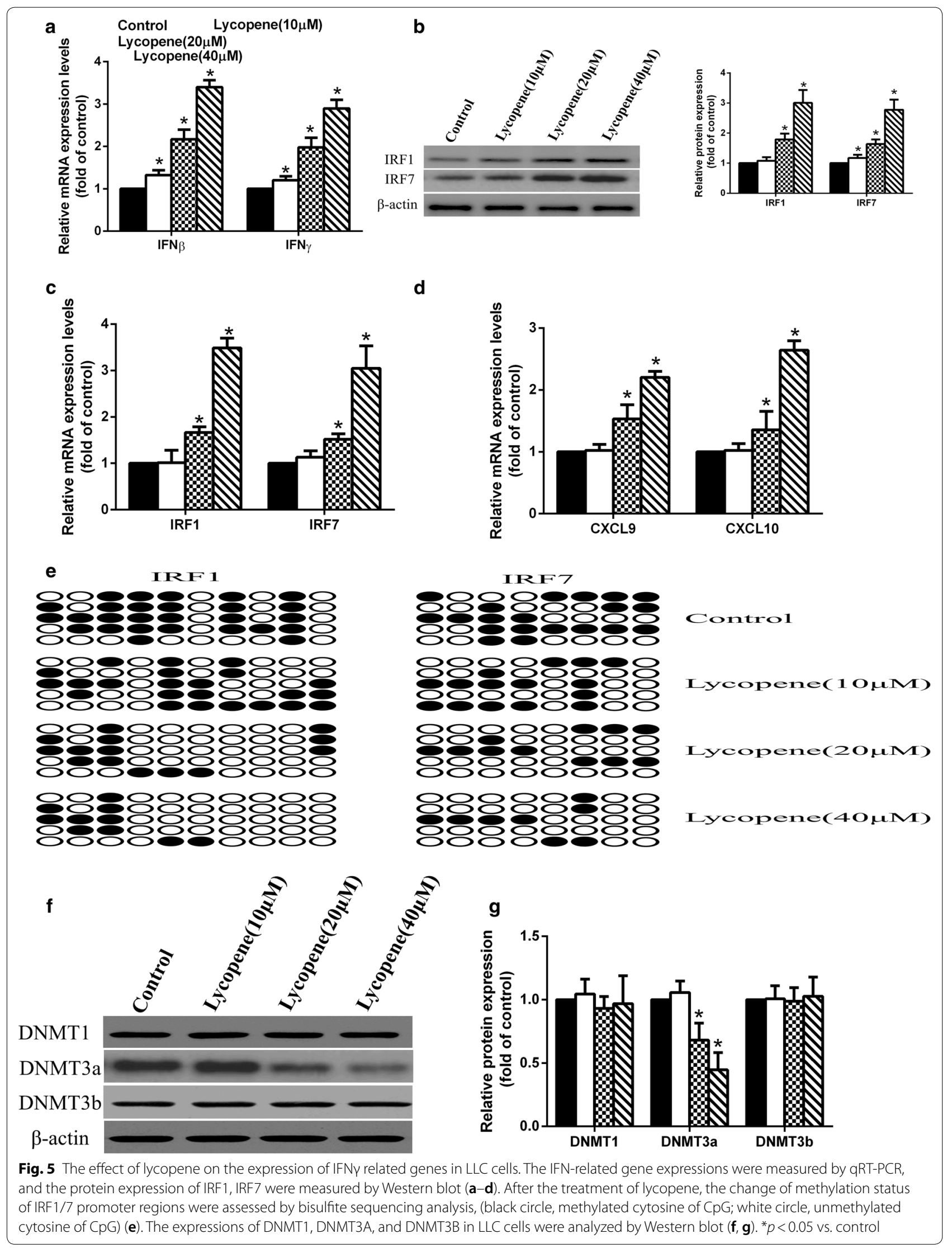




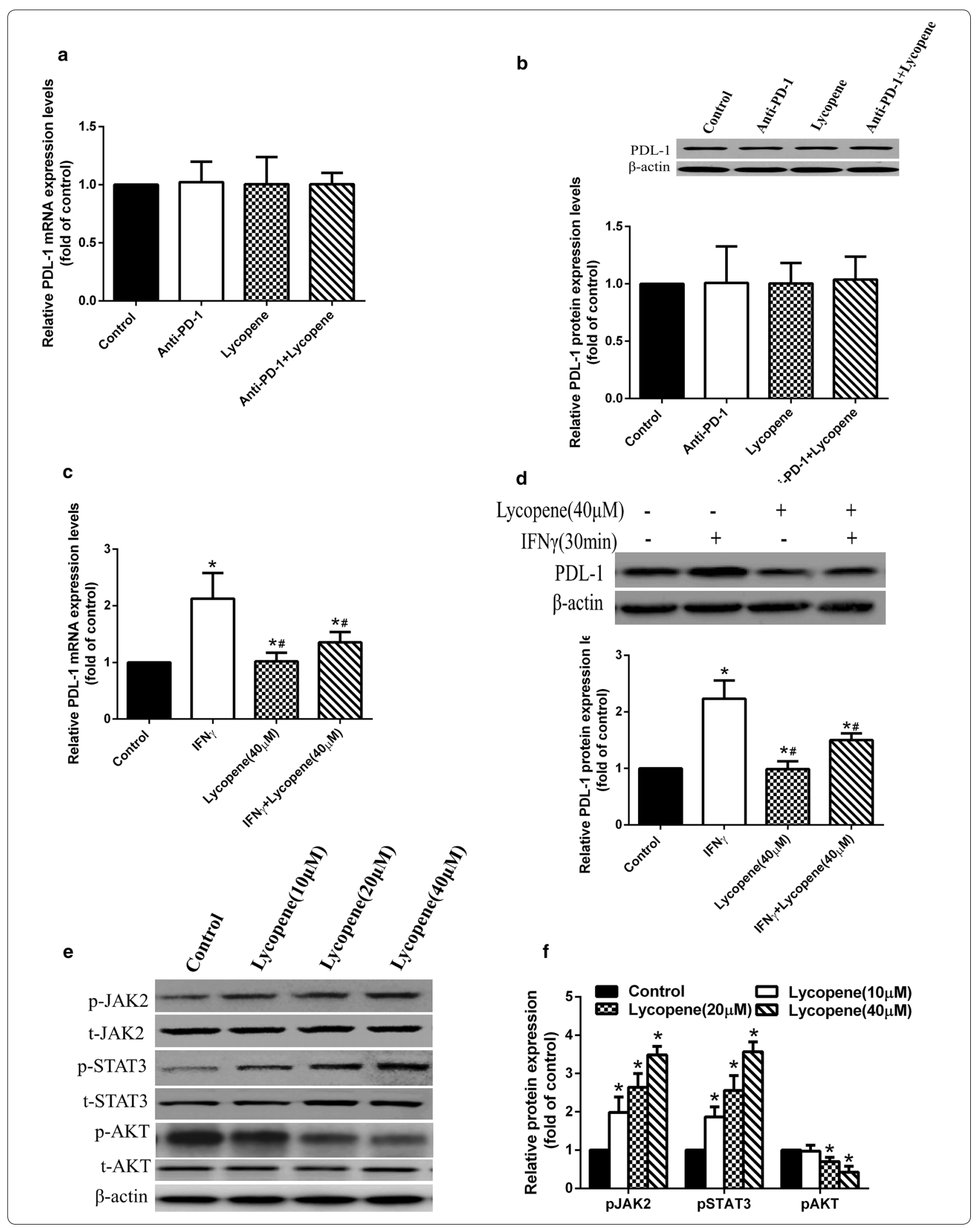


(See figure on previous page.)

Fig. 6 The effect and mechanism of lycopene on the expression of PDL-1 downstream the IFNy signaling. The mRNA and protein expression of PDL-1 in tumor were detected by qRt-PCR and Western blot $(\mathbf{a}, \mathbf{b})$. Lycopene inhibited the increased expression of PD-L1 induced by IFNY in LLC cells $(\mathbf{c}, \mathbf{d}),{ }^{*} p<0.05$ vs. control, ${ }^{*} p<0.05$ vs. IFNy $(n=6)$. Lycopene activated the JAK2 signal and inhibited AKT signaling to repress expression of PD-L1 in LLC cells $(\mathbf{e}, \mathbf{f}){ }^{*} p<0.05$ vs. control $(n=6)$

expected, the productions of IL-2 and IFN $\gamma$ were significantly increased in the spleen of mice treated with lycopene, whereas IL- 4 and IL-10 were inhibited. The ratio of CD4+/CD8+ cells in the spleen was enhanced in lycopene-treated mice compared to untreated mice, indicating that lycopene is able to promote immune response by enhancing the activation, growth and differentiation of $\mathrm{T}$ cells, as well as impact $T$ helper (Th)1/Th2 drift. In addition, increased IFN $\gamma$-expressing CD8+ cells in tumor tissues suggests that lycopene may disrupt the functions of PD-1 and PD-L1 to reduce tumor escaping from the immune system.

Interestingly, we found that lycopene promoted the mRNA expression levels of IFN $\gamma$ and IFN $\beta$ and their downstream gene expression including IRF1, IRF7, CXCL9 and CXCL10. It is known that IRF1 is an important factor involved in apoptosis, which can be stimulated upon stimuli such as IFN $\gamma$ and activated IFN $\beta$ gene [23]. Loss of IRF1 expression or function has been reported to be associated with several human cancers such as breast cancer and gastric cancer [24-26]. Another IRF family protein, IRF7, also plays critical roles in tumors. A previous study reported that silencing IRF7 could assist tumor cell to escape from the immune system, leading to increased tumor metastasis [27]. Essentially, IRF7 is also well-known by its regulatory role in the induction of IFN $\alpha / \beta$ genes [28]. Therefore, the elevated expression of IFN $\beta$ may be caused by the impact of lycopene on IRF7. Although IRF3 is also a master regulator for Type I IFN expression, we did not observe a significant change of IRF3 expression upon lycopene treatment. Additionally, no difference in IRF8 expression was exhibited upon lycopene treatment. It is known that IFN $\gamma$ induces IRF8 expression [29], and IRF8 expression could be repressed by DNA methylation [30]. Here, we found that lycopene treatment diminished the methylation levels of IRF1/7 promoters but not IRF8. It may indicate that lycopene may not directly function in IRF1/7 promoter methylation. However, we observed that lycopene significantly repressed the expression level of DNMT3a but did not affect DNMT1 and DNMT3b. Previous studies have demonstrated that DNMT3a is a negative regulator of IRF8 [31]. Therefore, this result further indicates that lycopene treatment affecting the mRNA levels of IRF1 and IRF7 may only be caused by its role in IFNY. Further study is needed to explain how lycopene regulates DNMT3a but showed no effect on IRF8.

The role of IFNY in anti-tumor immunity could be highlighted by resistance of tumors to interferons that leads to their evasion from the immune system [32]. Recently, immune checkpoint blockade (ICB) has been implicated in cancer treatments, which blocks inhibitory receptors on the surface of intra-tumoral effector $\mathrm{T}$ cells $[33,34]$. Results that ICB could induce production of intra-tumoral IFN $\gamma$ in mouse models and human patients, as well as the dependence of tumor infiltration on IFN $\gamma$ receptor by immune cells $[35,36]$, indicated a key role of IFN $\gamma$ in rejecting tumor. Studies from patients resistant to anti-PD1 therapy have also provided strong support for ICB-induced IFN $\gamma$ action directly on tumor cells [37, 38]. It would be interesting to further test these possibilities in the context of NSCLC.

$\mathrm{T}$ cell-secreted IFNY was reported to mediate the induction of PD-L1 expression in melanoma microenvironment [39]. In this study, we found that lycopene was able to decrease both mRNA and protein levels of PD-L1 upon IFNY stimulation in LLC cells. This process may be mediated by the regulatory effects of lycopene on AKT signaling. However, no change in PD-L1 was observed in tumors, suggesting that lycopene could disrupt the induction of PD-L1 by T cell-secreted IFN $\gamma$.

\section{Conclusion}

In conclusion, this is the first study discovering the role of lycopene in anti-PD-1 therapy. We have found that lycopene is a promising natural chemical that could synergistically function with anti-PD-1 to prevent tumorigenesis. Its immunomodulatory role assists anti-PD-1 to elevate the levels of IL-1 and IFNY but reduce the levels of IL-4 and IL-10 in the spleen. In addition to its effects on the $\mathrm{CD} 4+/ \mathrm{CD} 8+$ ratio, lycopene also increases the number of IFN $\gamma$ expressing CD8+ $\mathrm{T}$ cells in tumor tissues. Upon IFN $\gamma$ stimulation, lycopene represses PD-L1 expression via AKT signaling. These results demonstrate that lycopene could be applied to synergistically improve the efficiency of anti-PD-1 therapy. 


\section{Additional file}

Additional file 1: Figure S1. The photos for all tumors treated by the combined therapy of lycopene and anti-PD-1. Figure S2. After the treatment of lycopene and/or PD-1 therapy, the methylation status of IRF3/8 promoter regions were assessed by bisulfite sequencing analysis, methylated cytosine of $\mathrm{CpG} ; \mathrm{O}$, unmethylated cytosine of $\mathrm{CpG}$ ). Figure S3. Lycopene and PI3K-AKT inhibitor inhibited AKT signaling to repress expression of PD-L1 in LLC cells.

\section{Authors' contributions}

Conception and design: XJ, HW, WZ, XD and QY. Collection and assembly of data: FZ and MQ. Data analysis and interpretation: XJ and PY. Contribution of reagents, materials, and analysis tools wrote the paper: XJ, LS and XG. All authors read and approved the final manuscript.

\section{Acknowledgements}

Not applicable.

\section{Competing interests}

The authors declare that they have no competing interests.

\section{Availability of data and materials}

Not applicable.

\section{Consent for publication}

Not applicable.

\section{Ethics approval and consent to participate}

Not applicable.

\section{Funding}

This work was supported by Fund Program: Wuxi Municipal Health Bureau Project (MS201701) and Major Projects of Wuxi Municipal Health Committee (Z201811)

\section{Publisher's Note}

Springer Nature remains neutral with regard to jurisdictional claims in published maps and institutional affiliations.

Received: 22 August 2018 Accepted: 18 March 2019

Published online: 21 March 2019

\section{References}

1. Siegel RL, Miller KD, Jemal A. Cancer statistics, 2015. CA Cancer J Clin. 2015;65:5-29.

2. Siegel RL, Miller KD, Jemal A. Cancer statistics, 2018. CA Cancer J Clin. 2018;68:7-30

3. Goldstraw P, Crowley J, Chanksy K, Giroux DJ, Groome PA, Rami-Porta R, Postmus PE, Rusch V, Sobin L. The IASLC lung cancer staging project: proposals for the revision of the TNM stage groupings in the forthcoming (seventh) edition of the TNM classification of malignant tumors (vol 8, pg 706-714, 2007). J Thorac Oncol. 2007;2:985

4. Wu YL, Zhou CC, Hu CP, Feng JF, Lu S, Huang YC, Li W, Hou M, Shi JH, Lee KY, Xu CR, Massey D, Kim M, Shi Y, Geater SL. Afatinib versus cisplatin plus gemcitabine for first-line treatment of Asian patients with advanced non-small-cell lung cancer harbouring EGFR mutations (LUX-Lung 6): an open-label, randomised phase 3 trial. Lancet Oncol. 2014;15:213-22.

5. Shaw AT, Kim DW, Nakagawa K, Seto T, Crino L, Ahn MJ, De Pas T, Besse B, Solomon BJ, Blackhall F, Wu YL, Thomas M, O'Byrne KJ, Moro-Sibilot D, Camidge DR, Mok T, Hirsh V, Riely GJ, lyer S, Tassell V, Polli A, Wilner KD, Janne PA. Crizotinib versus chemotherapy in advanced ALK-positive lung cancer. N Engl J Med. 2013;368:2385-94.
6. Daskivich TJ, Belldegrun A. Re: safety, activity, and immune correlates of anti-PD-1 antibody in cancer. Eur Urol. 2015;67:816-7.

7. Herbst RS, Soria JC, Kowanetz M, Fine GD, Hamid O, Gordon MS, Sosman JA, McDermott DF, Powderly JD, Gettinger SN, Kohrt HEK, Horn L, Lawrence DP, Rost S, Leabman M, Xiao YY, Mokatrin A, Koeppen $\mathrm{H}$, Hegde PS, Mellman I, Chen DS, Hodi FS. Predictive correlates of response to the antiPD-L1 antibody MPDL3280A in cancer patients. Nature. 2014:515:563.

8. Garon EB, Rizvi NA, Hui RN, Leighl N, Balmanoukian AS, Eder JP, Patnaik A, Aggarwal C, Gubens M, Horn L, Carcereny E, Ahn MJ, Felip E, Lee JS, Hellmann MD, Hamid O, Goldman JW, Soria JC, Dolled-Filhart M, Rutledge RZ, Zhang J, Lunceford JK, Rangwala R, Lubiniecki GM, Roach C, Emancipator K, Gandhi L, Investigators K. Pembrolizumab for the treatment of nonsmall-cell lung cancer. N Engl J Med. 2015;372:2018-28.

9. Paulsen EE, Kilvaer TK, Rakaee M, Richardsen E, Hald SM, Andersen S, Busund LT, Bremnes RM, Donnem T. CTLA-4 expression in the non-small cell lung cancer patient tumor microenvironment: diverging prognostic impact in primary tumors and lymph node metastases. Cancer Immunol Immunother. 2017;66:1449-61.

10. Zou WP, Chen LP. Inhibitory B7-family molecules in the tumour microenvironment. Nat Rev Immunol. 2008:8:467-77.

11. Herbst RS, Baas P, Kim DW, Felip E, Perez-Gracia JL, Han JY, Molina J, Kim JH, Arvis CD, Ahn MJ, Majem M, Fidler MJ, de Castro G, Garrido M, Lubiniecki GM, Shentu Y, Im E, Dolled-Filhart M, Garon EB. Pembrolizumab versus docetaxel for previously treated, PD-L1-positive, advanced non-small-cell lung cancer (KEYNOTE-010): a randomised controlled trial. Lancet. 2016;387:1540-50.

12. King-Batoon A, Leszczynska JM, Klein CB. Modulation of gene methylation by genistein or lycopene in breast cancer cells. Environ Mol Mutagen. 2008:49:36-45.

13. Fu LJ, Ding YB, Wu LX, Wen CJ, Qu Q, Zhang X, Zhou HH. The effects of lycopene on the methylation of the GSTP1 promoter and global methylation in prostatic cancer cell lines PC3 and LNCaP. Int J Endocrinol. 2014. https://doi.org/10.1155/2014/620165.

14. Lai Q, Wang HY, Li AG, Xu YH, Tang L, Chen Q, Zhang CF, Gao Y, Song JF, Du ZZ. Decitibine improve the efficiency of anti-PD-1 therapy via activating the response to IFN/PD-L1 signal of lung cancer cells. Oncogene. 2018;37:2302-12

15. Garon E, Gandhi L, Rizvi N, Hui R, Balmanoukian A, Patnaik A, Eder J, Blumenshein G, Aggarwal C, Soria J. Lba43antitumor activity of pembrolizumab (pembro; Mk-3475) and correlation with programmed death ligand 1 (pd-L1) expression in a pooled analysis of patients (pts) with advanced non-small cell lung carcinoma (nsclc). Ann Oncol. 2014:25:1. https://doi.org/10.1093/annonc/mdu438.

16. Gainor JF, Shaw AT, Sequist LV, Fu X, Azzoli CG, Piotrowska Z, Huynh TG, Zhao L, Fulton L, Schultz K. EGFR mutations and ALK rearrangements are associated with low response rates to PD-1 pathway blockade in nonsmall cell lung cancer (NSCLC): a retrospective analysis. Clinl Cancer Res. 2016;22:4585-93.

17. Graff RE, Pettersson A, Lis RT, Ahearn TU, Markt SC, Wilson KM, Rider JR, Fiorentino M, Finn S, Kenfield SA, Loda M, Giovannucci EL, Rosner B, Mucci LA. Dietary lycopene intake and risk of prostate cancer defined by ERG protein expression. Am J Clin Nutr. 2016;103:851-60.

18. Aizawa K, Liu C, Tang SY, Veeramachaneni S, Hu KQ, Smith DE, Wang XD. Tobacco carcinogen induces both lung cancer and non-alcoholic steatohepatitis and hepatocellular carcinomas in ferrets which can be attenuated by lycopene supplementation. Int J Cancer. 2016;139:1171-81.

19. Abar L, Vieira AR, Aune D, Stevens C, Vingeliene S, Navarro Rosenblatt DA, Chan D, Greenwood DC, Norat T. Blood concentrations of carotenoids and retinol and lung cancer risk: an update of the WCRF-AICR systematic review of published prospective studies. Cancer Med. 2016:5:2069-83.

20. Zhou SK, Zhang RL, Bi TN, Lu Y, Jiang LX. Inhibitory effect of lycopene against the growth of human gastric cancer cells. Afr J Tradit Complement Altern Med. 2016;13:184-90.

21. Assar EA, Vidalle MC, Chopra M, Hafizi S. Lycopene acts through inhibition of IKB kinase to suppress NF-KB signaling in human prostate and breast cancer cells. Tumor Biol. 2016:37:9375-85.

22. Liu C-B, Wang R, Yi Y-F, Gao Z, Chen Y-Z. Lycopene mitigates $\beta$-amyloid induced inflammatory response and inhibits NF-kB signaling at the choroid plexus in early stages of Alzheimer's disease rats. J Nutr Biochem. 2018:53:66-71 
23. Tomita Y, Bilim V, Hara N, Kasahara T, Takahashi K. Role of IRF-1 and caspase-7 in IFN-gamma enhancement of Fas-mediated apoptosis in ACHN renal cell carcinoma cells. Int J Cancer. 2003;104:400-8.

24. Tamura G, Ogasawara S, Nishizuka S, Sakata K, Maesawa C, Suzuki Y, Terashima M, Saito K, Satodate R. Two distinct regions of deletion on the long arm of chromosome 5 in differentiated adenocarcinomas of the stomach. Can Res. 1996;56:612-5.

25. Doherty GM, Goucher L, Sorenson K, Lowney J. Interferon regulatory factor expression in human breast cancer. Ann Surg. 2001;233:623-8.

26. Cavalli LR, Riggins RB, Wang AT, Clarke R, Haddad BR. Frequent loss of heterozygosity at the interferon regulatory factor-1 gene locus in breast cancer. Breast Cancer Res Treat. 2010;121:227-31.

27. Bidwell BN, Slaney CY, Withana NP, Forster S, Cao Y, Loi S, Andrews D, Mikeska T, Mangan NE, Samarajiwa SA, de Weerd NA, Gould J, Argani P, Moller A, Smyth MJ, Anderson RL, Hertzog PJ, Parker BS. Silencing of Irf7 pathways in breast cancer cells promotes bone metastasis through immune escape. Nat Med. 2012;18:1224-31.

28. Honda K, Yanai H, Negishi H, Asagiri M, Sato M, Mizutani T, Shimada N, Ohba Y, Takaoka A, Yoshida N. IRF-7 is the master regulator of type-I interferon-dependent immune responses. Nature. 2005:434:772.

29. Liu KB, Abrams SI. Coordinate regulation of IFN consensus sequencebinding protein and caspase- 1 in the sensitization of human colon carcinoma cells to Fas-mediated apoptosis by IFN-gamma. J Immunol. 2003;170:6329-37.

30. Yang DF, Thangaraju M, Greeneltch K, Browning DD, Schoenlein PV, Tamura T, Ozato K, Ganapathy V, Abrams SI, Liu KB. Repression of IFN regulatory factor 8 by DNA methylation is a molecular determinant of apoptotic resistance and metastatic phenotype in metastatic tumor cells. Can Res. 2007;67:3301-9.

31. Park-Min KH. Epigenetic regulation of bone cells. Connect Tissue Res. 2017:58:76-89.
32. Ivashkiv LB. IFNgamma: signalling, epigenetics and roles in immunity, metabolism, disease and cancer immunotherapy. Nat Rev Immunol. 2018:18:545-58.

33. Callahan MK, Postow MA, Wolchok JD. Targeting T cell co-receptors for cancer therapy. Immunity. 2016;44:1069-78.

34. Minn AJ, Wherry EJ. Combination cancer therapies with immune checkpoint blockade: convergence on interferon signaling. Cell. 2016;165:272-5.

35. Peng W, Liu C, Xu C, Lou Y, Chen J, Yang Y, Yagita H, Overwijk WW, Lizee G, Radvanyi L, Hwu P. PD-1 blockade enhances T-cell migration to tumors by elevating IFN-gamma inducible chemokines. Can Res. 2012;72:5209-18.

36. Shi LZ, Fu T, Guan B, Chen J, Blando JM, Allison JP, Xiong L, Subudhi SK, Gao J, Sharma P. Interdependent IL-7 and IFN-gamma signalling in T-cell controls tumour eradication by combined alpha-CTLA-4+ alpha-PD-1 therapy. Nat Commun. 2016;7:12335.

37. Shin DS, Zaretsky JM, Escuin-Ordinas H, Garcia-Diaz A, Hu-Lieskovan S, Kalbasi A, Grasso CS, Hugo W, Sandoval S, Torrejon DY, Palaskas N, Rodriguez GA, Parisi G, Azhdam A, Chmielowski B, Cherry G, Seja E, BerentMaoz B, Shintaku IP, Le DT, Pardoll DM, Diaz LA Jr, Tumeh PC, Graeber TG, Lo RS, Comin-Anduix B, Ribas A. Primary resistance to PD-1 blockade mediated by JAK1/2 mutations. Cancer Discov. 2017;7:188-201.

38. Zaretsky JM, Garcia-Diaz A, Shin DS, Escuin-Ordinas H, Hugo W, HuLieskovan S, Torrejon DY, Abril-Rodriguez G, Sandoval S, Barthly L, Saco J, Homet Moreno B, Mezzadra R, Chmielowski B, Ruchalski K, Shintaku IP, Sanchez PJ, Puig-Saus C, Cherry G, Seja E, Kong X, Pang J, Berent-Maoz B, Comin-Anduix B, Graeber TG, Tumeh PC, Schumacher TN, Lo RS, Ribas A. Mutations associated with acquired resistance to PD-1 blockade in melanoma. N Engl J Med. 2016;375:819-29.

39. Spranger S, Spaapen RM, Zha Y, Williams J, Meng Y, Ha TT, Gajewski TF. Upregulation of $\mathrm{PD}-\mathrm{L} 1, \mathrm{IDO}$, and T-regs in the melanoma tumor microenvironment is driven by CD8(+) T cells. Sci Transl Med. 2013:5:200ra116.
Ready to submit your research? Choose BMC and benefit from:

- fast, convenient online submission

- thorough peer review by experienced researchers in your field

- rapid publication on acceptance

- support for research data, including large and complex data types

- gold Open Access which fosters wider collaboration and increased citations

- maximum visibility for your research: over $100 \mathrm{M}$ website views per year

At BMC, research is always in progress.

Learn more biomedcentral.com/submissions 